LA-UR- 94-3611

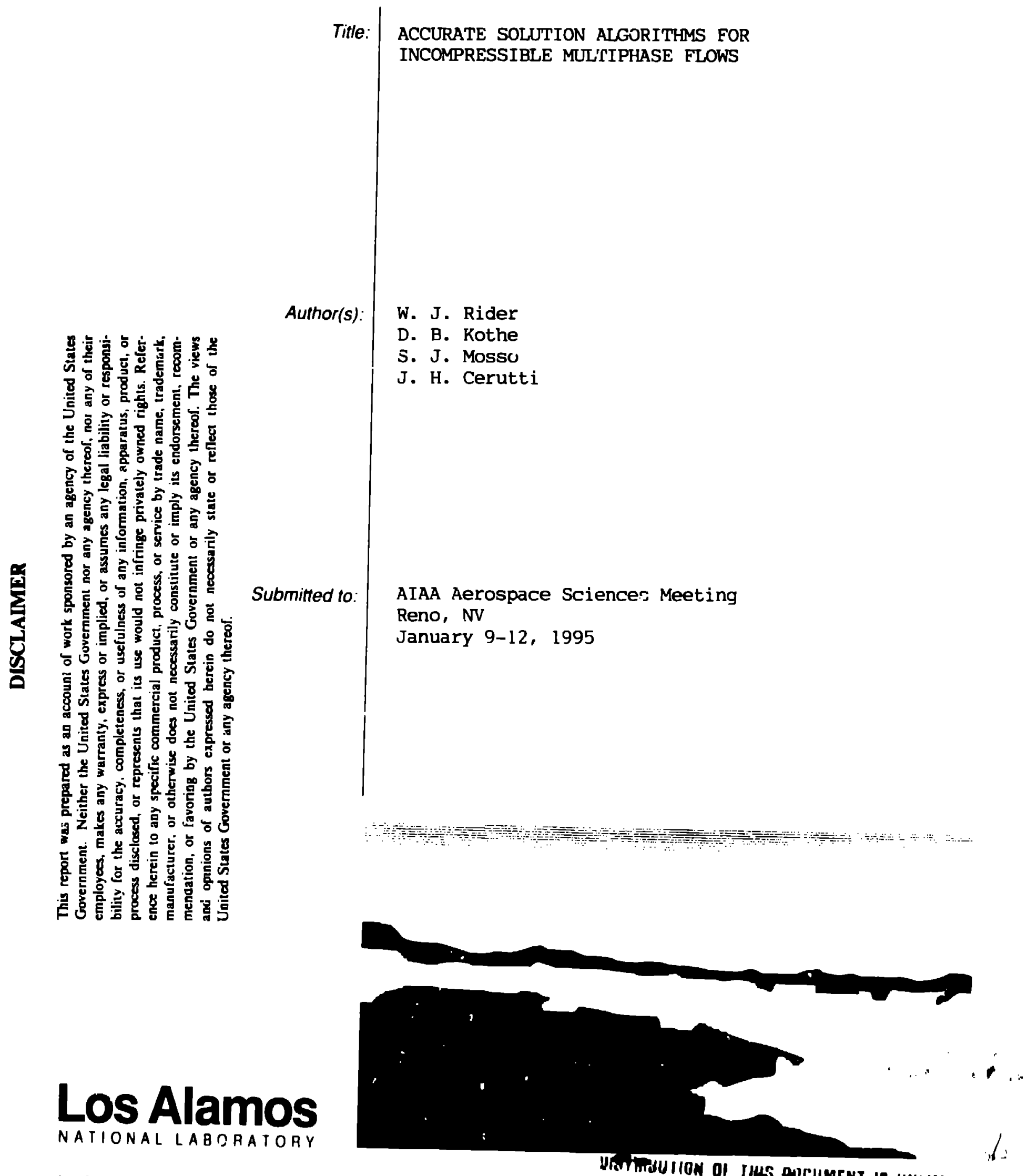

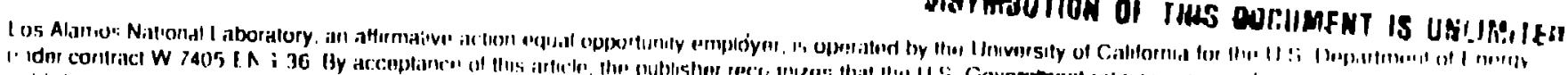

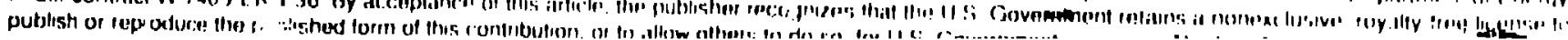




\title{
ACCurate Solution Algorithms for InCompressible Multiphase Flows •
}

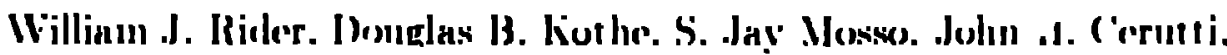 \\ I.ss . Ilanos . National Laboratory

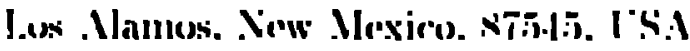 \\ allil \\ Juhn I. Ilochstein \\ Mexhanical lingmererme Department \\ Iromphis tiale I'niversily

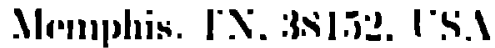 \\ (D)tuluer I!). I!!!)!
}

\begin{abstract}
Alstract

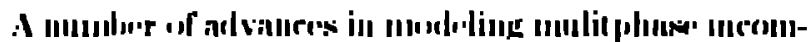

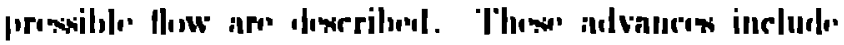

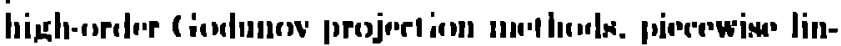

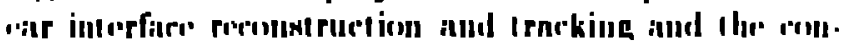

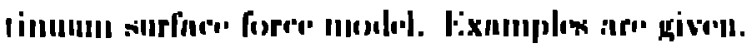

\section{Introduction}

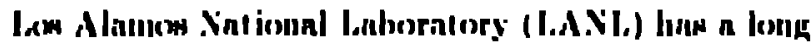
history in centupuational Auid lyunuies. A purticularly

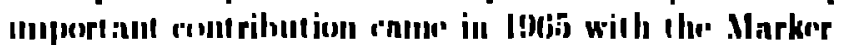

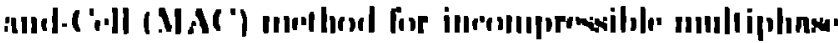

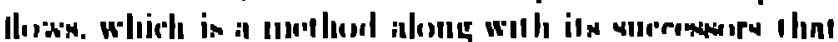

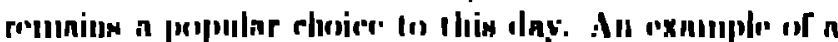

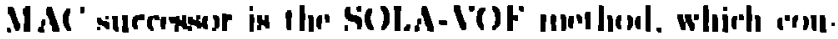

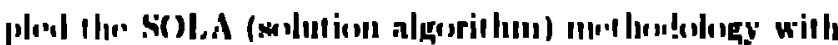

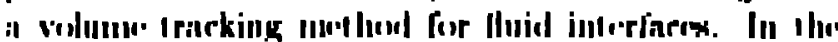

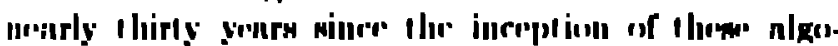

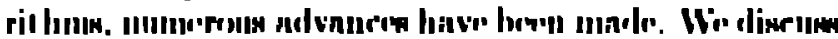

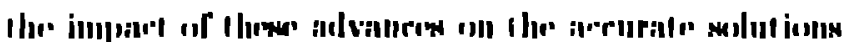
of inromprowils|r imultiplinew flows.

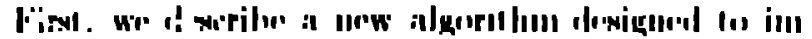

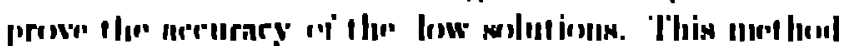

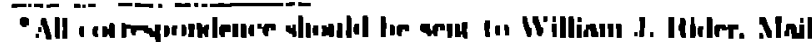

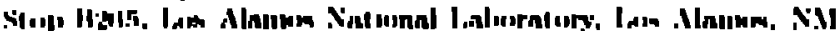

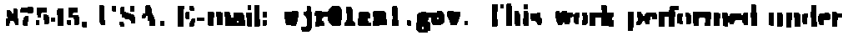

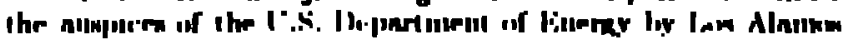

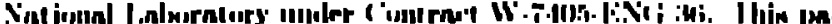

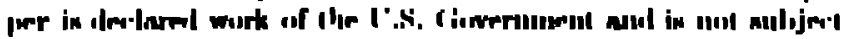

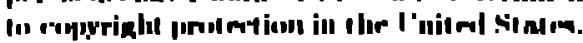

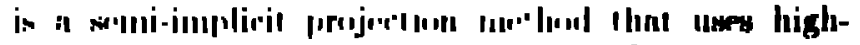

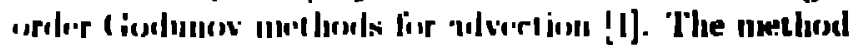

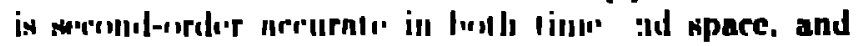

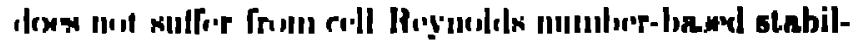

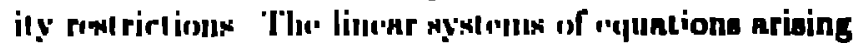

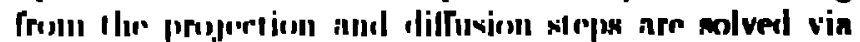
multigricl menthoels. 'Tlue algorishun is constructed for $n$

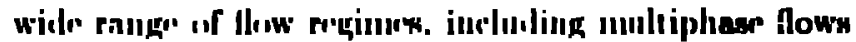
where density ration itreses interfacess ran lse arbitrarily

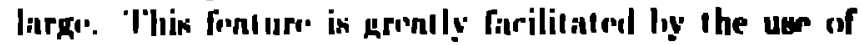
volumer t rarking with this methorl. In ronjunction with low orm or formuln! ione and i he lillering of nonm. noidn'

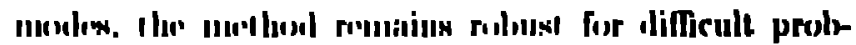

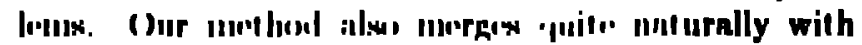

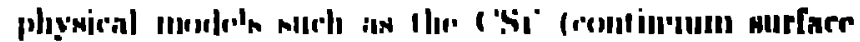

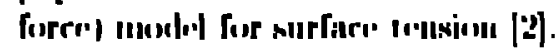

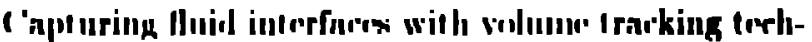

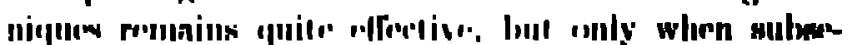

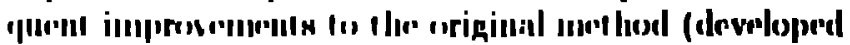

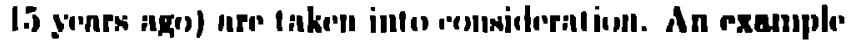

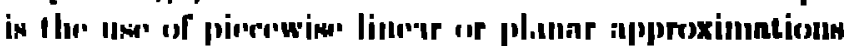

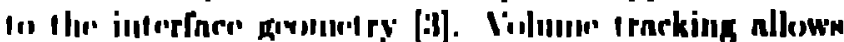

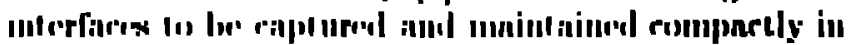

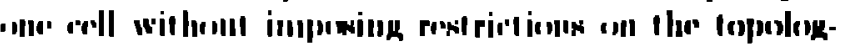
irnl romplexily or I/er nemlure of interfarm that ran

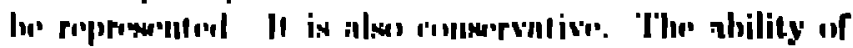

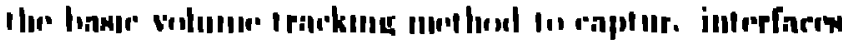

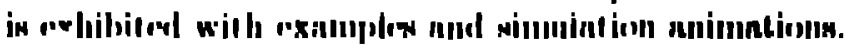

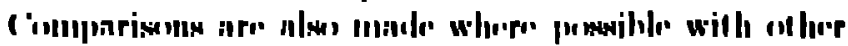
intrerfure rapt uriuk algurıl imms.

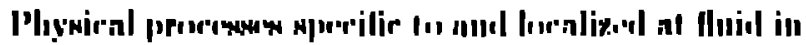




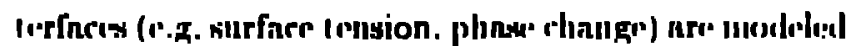

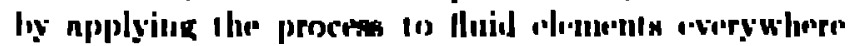
within the interface transition rogiuns. Surface pros

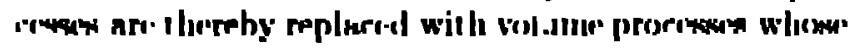
imteral offert properly reproslueres the cloximel interfinco

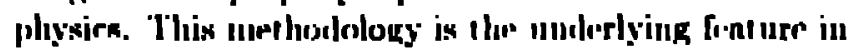
the ('SF menhod for surfner tension. whirh lins prosun mecrestul in a varioly of at udies. The o 'St mothod lifin all tupological roal rirtions (lypirnlly inlunrent in modols for surfner truxion) without sacrilicing necurary. robust-

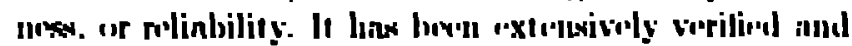

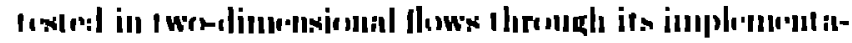
tim in in elassical algorithm for fres surfine "Ilows. where

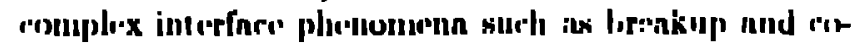

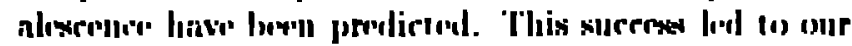

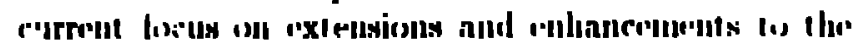
('SY morhoul. nnmoly thrmelimensionality. an inolicit

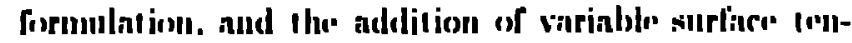

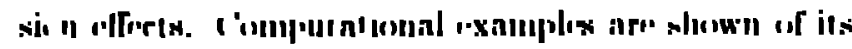
apahilitim.

\section{Projection/Ciodumov Methorls}

We

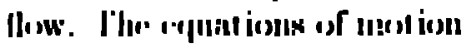

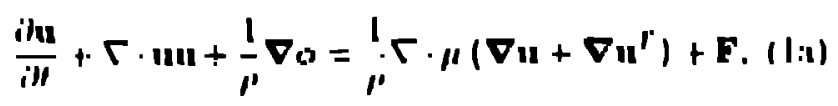

lhe ronservation of mows

$$
\Gamma \cdot \mathbf{n}=1) \text {, }
$$

and deneily nud viurmity emonport

$$
\frac{i p_{p}}{\text { ill }}+\mathbf{u} \cdot \nabla_{\mu}=11 \text {. }
$$

illiel

$$
\frac{i 11}{i 11}+11 \cdot \nabla, 1=11
$$

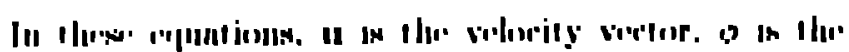

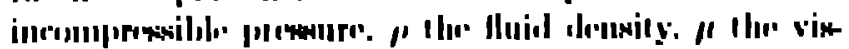

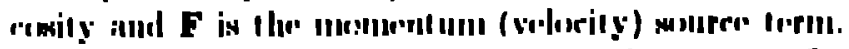

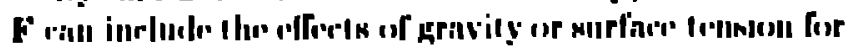

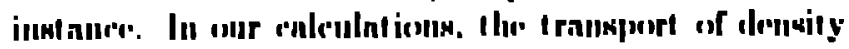
alld vinroxily in molverl with onle enpalionl.

$$
\text { iif } 110 \nabla f \cdot 1 \text {. }
$$

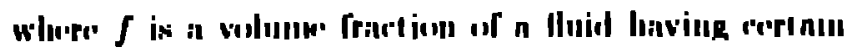

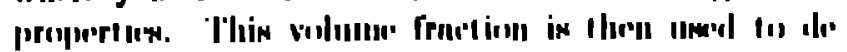

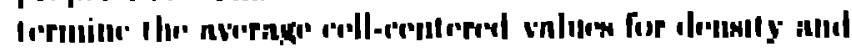

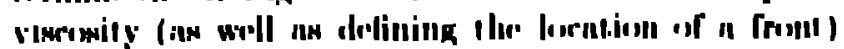

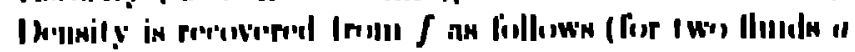
nnil $b$.

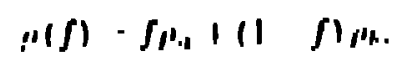

inul nimilrly visuroxity

$$
\mu(\rho)=f \mu_{u}+(1-\rho) \mu_{b}
$$

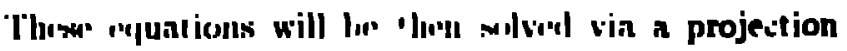
menthoul diswribrol berlow.

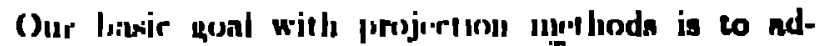
vilure a valuscily fielel. $V=\left(l^{-r} . l^{-y}\right)^{T}$ hy some convenirnt unenux ulisregardink the solenusidal nacure of $\mathbf{V}$. then rerover the propure whlonuidal velocity field, $v$ $\left(\Gamma \cdot V^{\prime}=(1)\right.$. 'It o munns to this end is a projection. $P$. which has llye illiert

$$
\mathbf{V}^{\prime l}=r(\mathbf{V})
$$

The' projmetion ntcomplislin thit through the decompo-

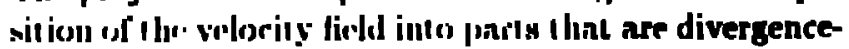
frim alud rurl-fruy. This is knuw'n as a llodge or Ilolmhultz drenumusition [-1]. The rurl-free portion will

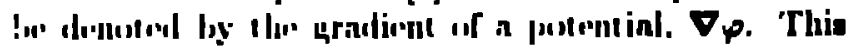
derompesil ion ran la, writlen

$$
V=V^{\prime I}+\pi \nabla_{r}
$$

whire $r=1 / \mu$.

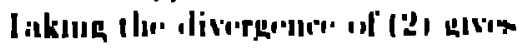

$$
\Gamma \cdot V=\Gamma \cdot V^{\prime \prime}+\Gamma \cdot \pi \nabla_{r}-\Gamma V=\Gamma \cdot \sigma \nabla \rho .
$$

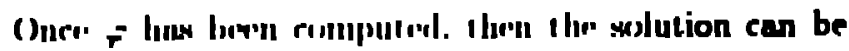
found through

$$
V^{\prime \prime}=\mathbf{V}-\boldsymbol{r} \boldsymbol{\nabla}^{\mathbf{r}}
$$

Whe will he concermerl with it ilaw of molution alHorithus known as approximnto projortion nethods.

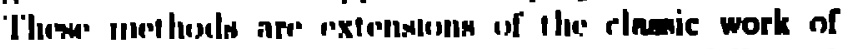

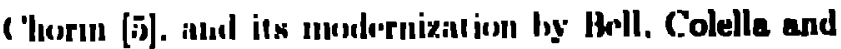
filuz [b] for molving lhe incoupprossiblo Navier-Stokea

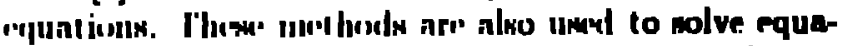
lions with virying ilensity [1]. IJrre wo focus on the ap-

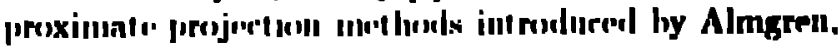
|brll nud Szymeznk [J].

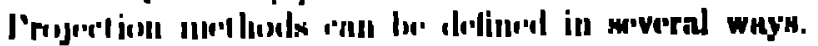

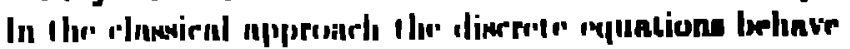
similnrly (1) the analyfir projeretion epreratore. l'nfor-

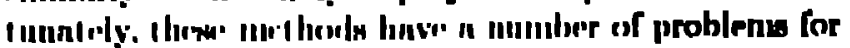

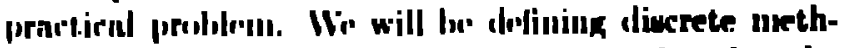

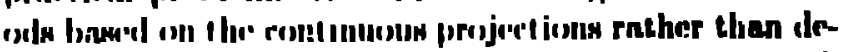

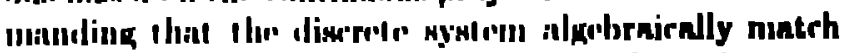

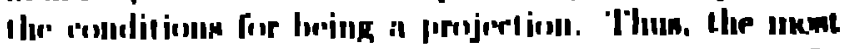

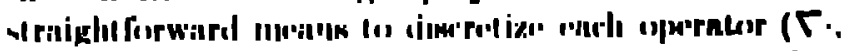

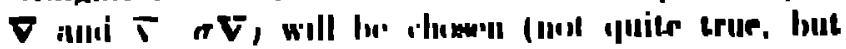
nenrly).

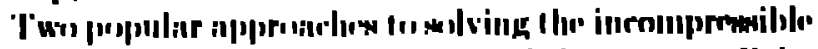

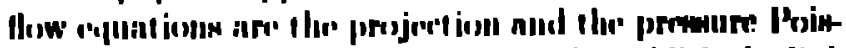

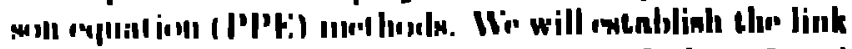

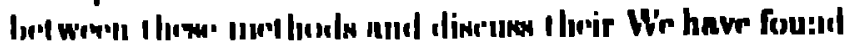

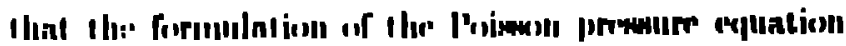

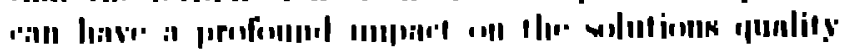




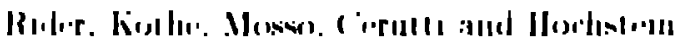

The most rohust formulation we foumel is formulate in in Ihe followilig fastion for a frartional step inethoul

$$
\Gamma \cdot \frac{1}{\rho^{n+\frac{1}{2}}} \nabla_{n}=\frac{\Gamma \cdot \mathbf{1}^{-n+1}}{\Delta t} .
$$

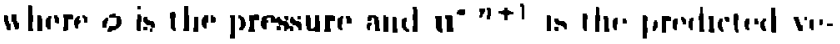
locity dolined by

$$
\begin{aligned}
& n^{* n+1}=\left(1-\frac{\Delta t}{2} \frac{1}{\mu^{n+i}} \Gamma \cdot \mu^{n+!}(\nabla+\nabla r)\right)^{-!}
\end{aligned}
$$

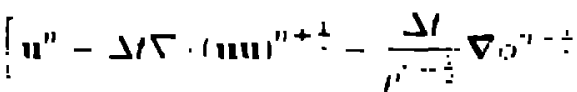

$$
\begin{aligned}
& \left.+\Delta / \mathbf{F}^{\prime+!}+\frac{1}{2} \frac{\Delta t}{\mu^{n+!}} \Gamma \cdot \mu^{++ \pm}\left(\nabla_{\mathbf{u}}+\nabla_{\mathbf{u}}\right)^{\prime \prime}\right) ! \\
& +\frac{I t}{l^{\prime+!}} \nabla a^{n-!}
\end{aligned}
$$

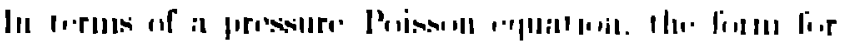

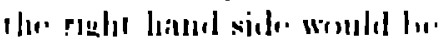

$$
\begin{aligned}
& \Gamma\left(\frac{1}{\mu^{\prime \prime+!}}+\mu^{\prime+!}\left(\nabla_{11}-\nabla_{1}\right)^{\prime \prime+}\right. \\
& \left.-\Gamma \cdot|\mathbf{u u |}|^{\prime+}=+\mathbf{F}^{\prime+!}+\frac{\mathbf{u t}^{\prime \prime}}{\Delta t}\right)
\end{aligned}
$$

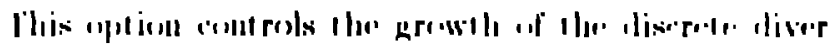

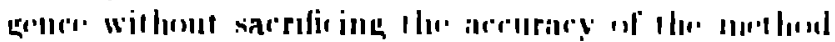
I full exposition on this subjerel a given in [x. !1].

Whell using approximalo projectiolss it is inportant

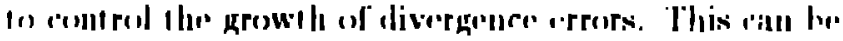

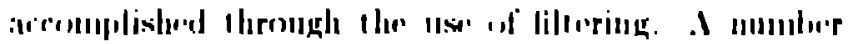

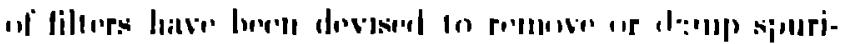

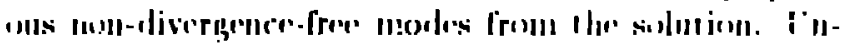

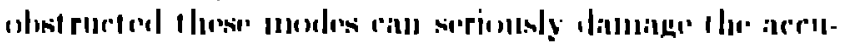

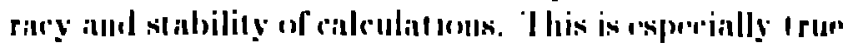

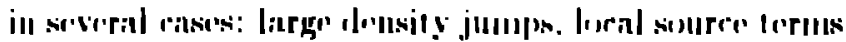

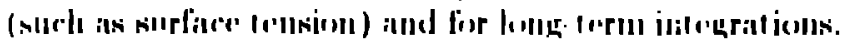

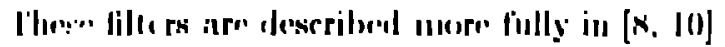

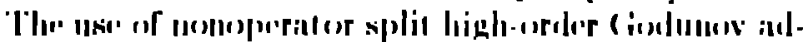

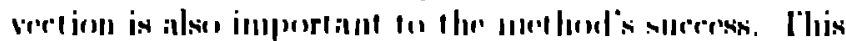

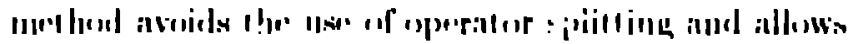

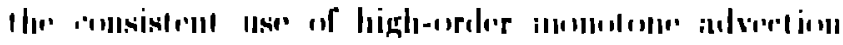

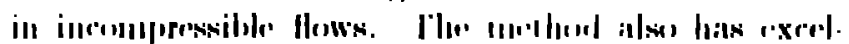

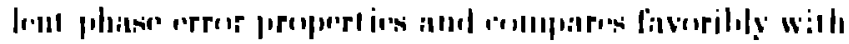

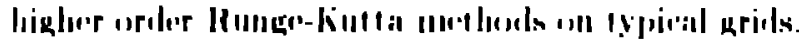

|ום

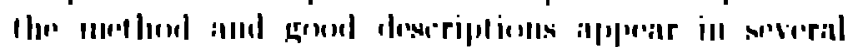

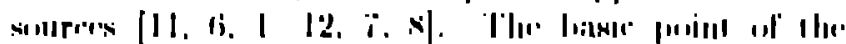

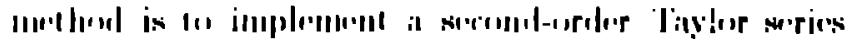

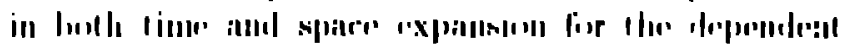

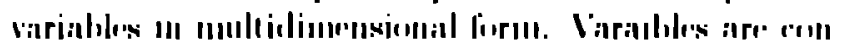

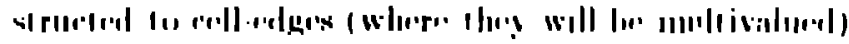

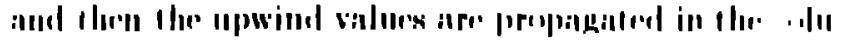

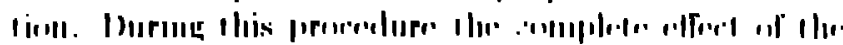

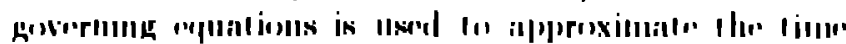

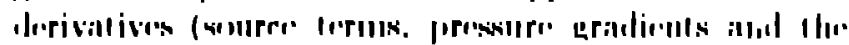

incompremsility entstru ... ). The une of the incomprest-

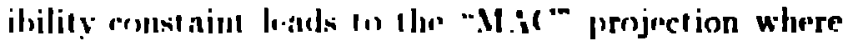

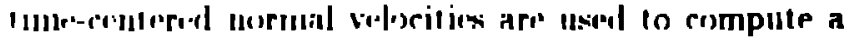

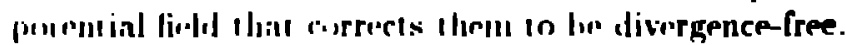

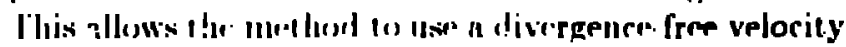
firlat for the purposer of advertion (even with an approximal, projertionl alld maint ain serond-order accuracy.

Siveral pronts are importanl (1) entphasize. This merloul is mot hemul hy a stability resiriction related to the Reynolds number. Thus this method can be used in compute lomh viseons ant inviscid Hows. Resules

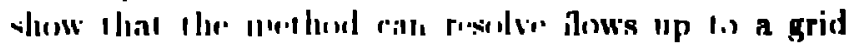

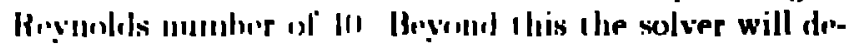
gracle is a crareful lisshion and pror!uce physical. but

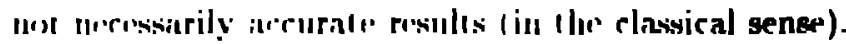

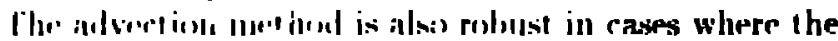

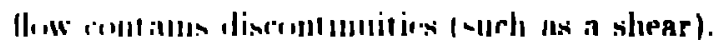

\section{Inlorfiker Kinmuatics}

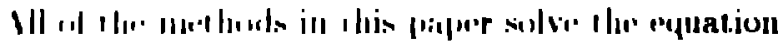

$$
\frac{i f}{i 11}-\mathbf{u} \cdot \nabla f=11 \text {. }
$$

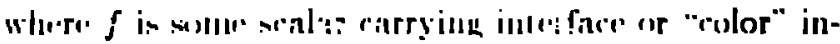
formatioul. An repuivalene engutull for incompressible Hins is

$$
\frac{i l f}{i l l}+\Gamma \cdot(\mathbf{u} f)=11
$$

$\rightarrow \min \Gamma \cdot 11=11$.

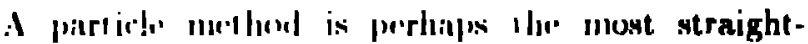

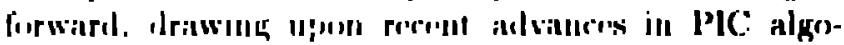
rithuss fla\}. Parlicles are issigned a mass arcording to

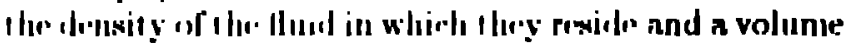

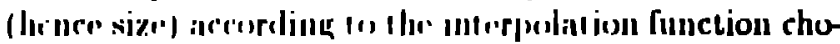

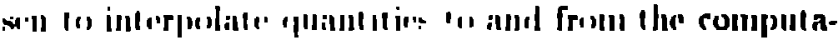

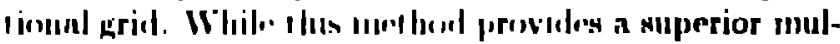

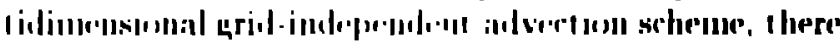

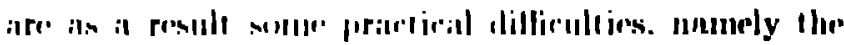

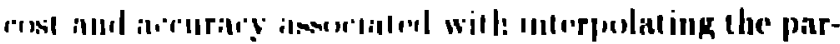

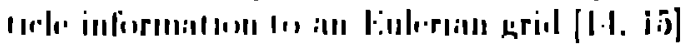

Simply dientrelsing 111 wilh a high rewolution finito

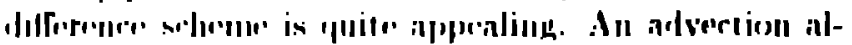

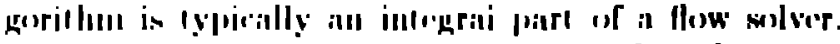

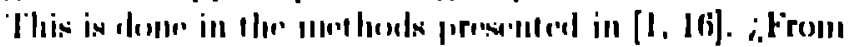

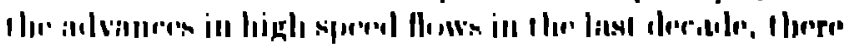

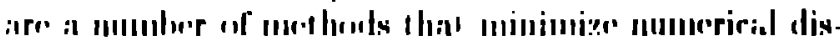

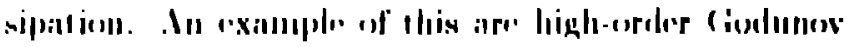

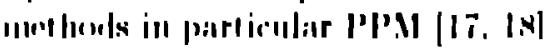

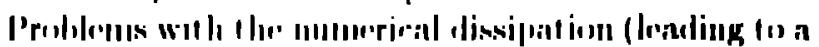

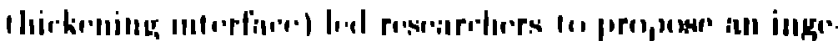

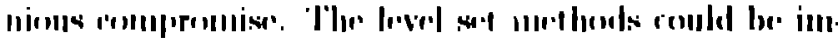

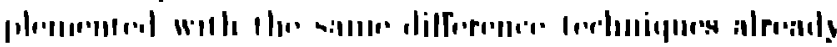

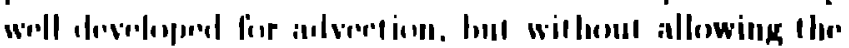

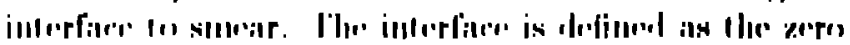




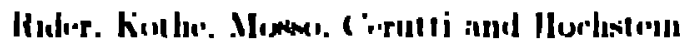

leviel sel of a distance functicon. 2 . from that intorfince.

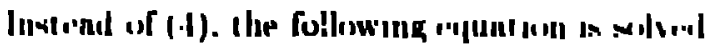

$$
\frac{\partial u}{i t}+u \cdot \nabla u=u \text {. }
$$

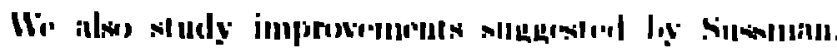
Simerrekn and (Osher ! l!!!.

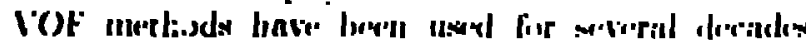
starting at the uational laboratorios (l.iverumere [2(1)] nni I.us dlanıos [2l] and Inter Snodia [22]). ?'lue onrlier work

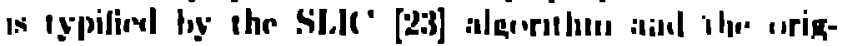

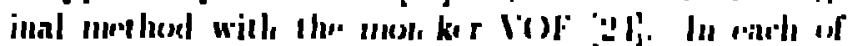

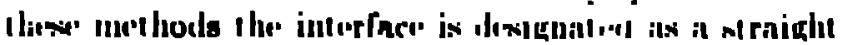

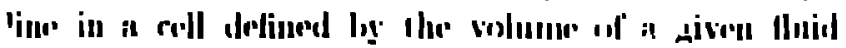

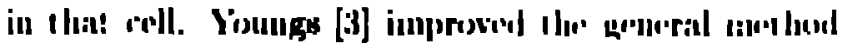

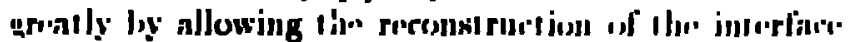

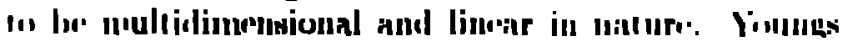

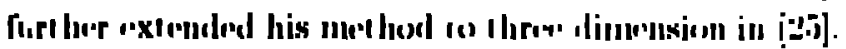

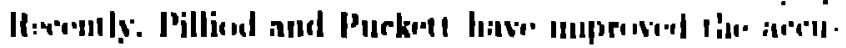

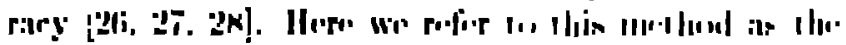

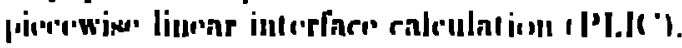

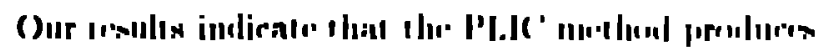

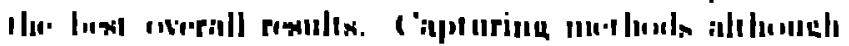

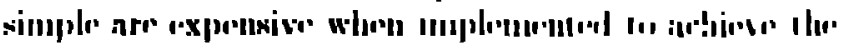

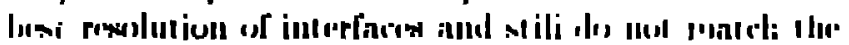

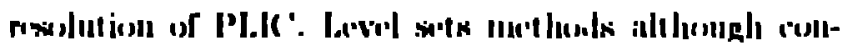

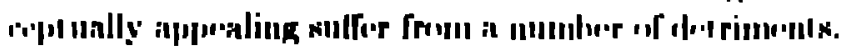

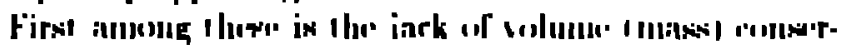

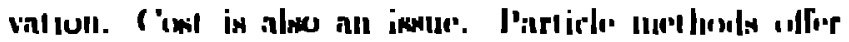

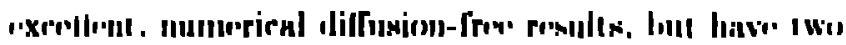

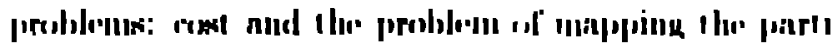

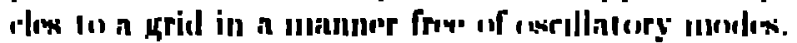

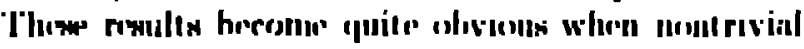

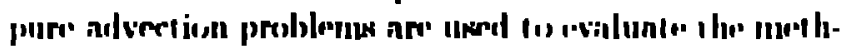

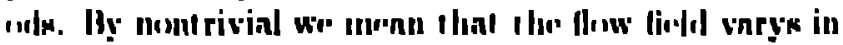

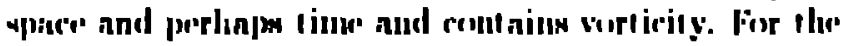

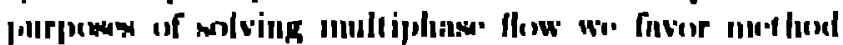

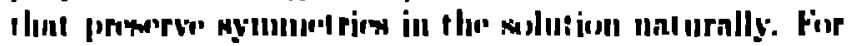

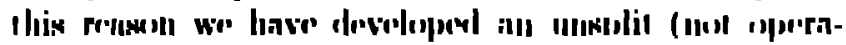

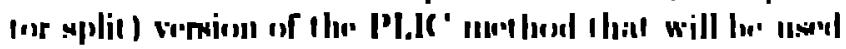

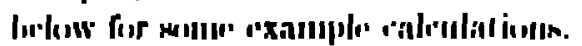

\section{IV. [utcrfacr Druamiars}

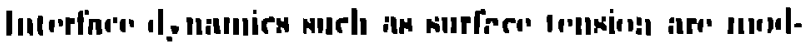

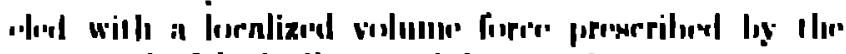

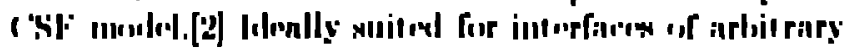

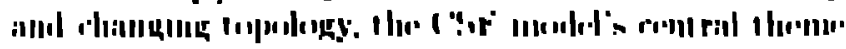

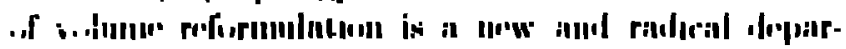

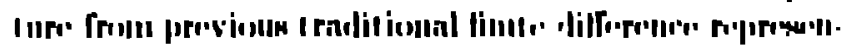

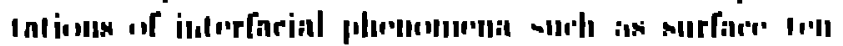

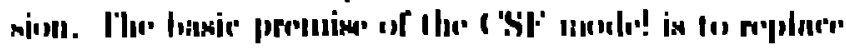

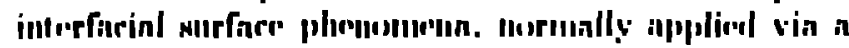

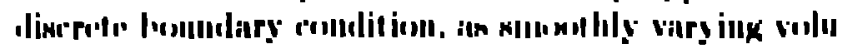

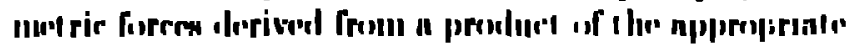

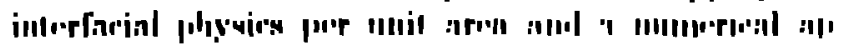

loreximation to the surfare linterfare) inelta function.

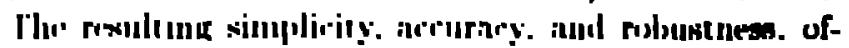

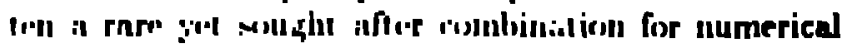

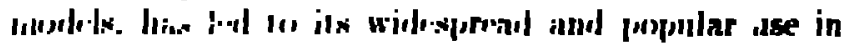

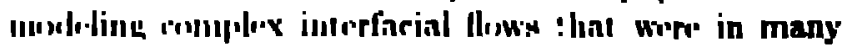

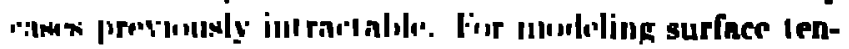

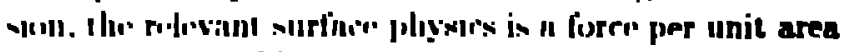

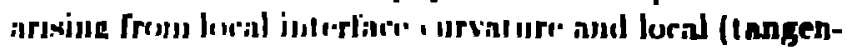

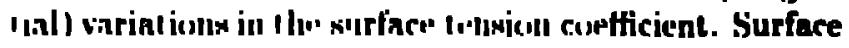

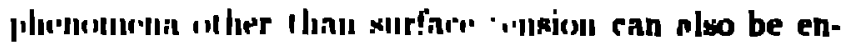

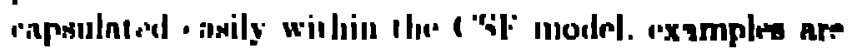

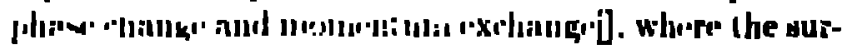

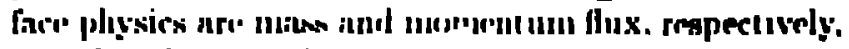

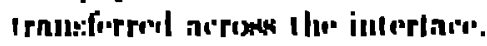

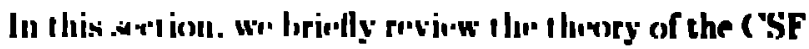

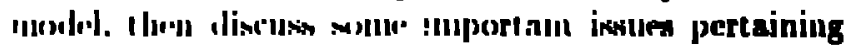
11 the iocurat, formulation of the neersary discrete

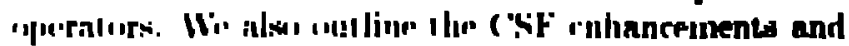

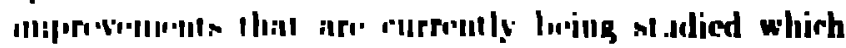
slombl allow a murne ellirenent monleling cif a wider variety of interfinclial Il-wss.

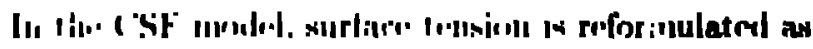

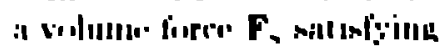

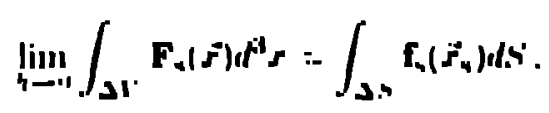

Where $r$ is a foul ,

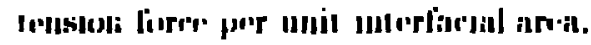

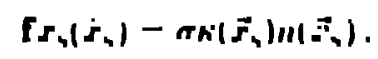

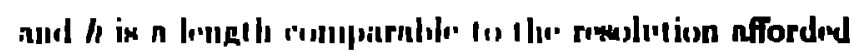

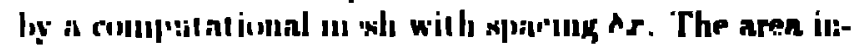

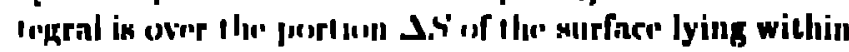
the shuall volumir ur inlouration 3 .

Since interfacis having surface lension are tracked

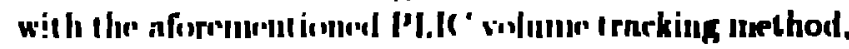

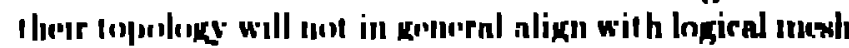

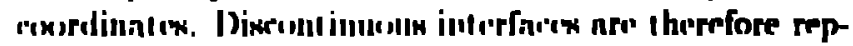

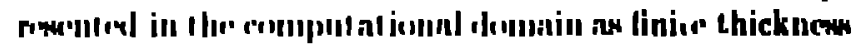
Irankilion reginus within welieh lluinl solumer irartionss

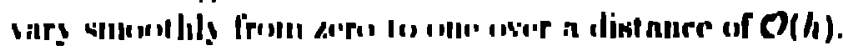

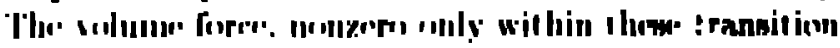

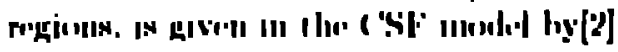

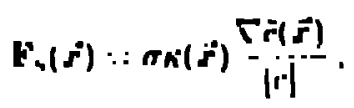

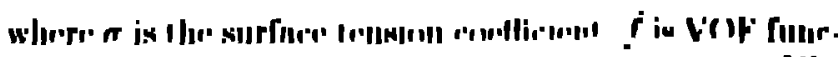

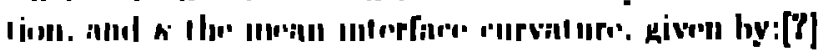

$$
n \cdot(\Gamma \cdot n) \ldots
$$

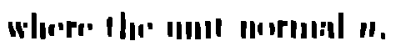

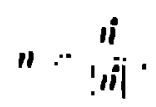




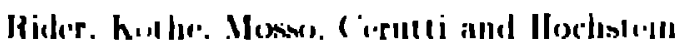

is derived from a normal vector $\bar{n}$.

$$
\vec{n}=\Gamma \rho .
$$

- hat is the gradient of VOF laia. Bratisie the curvat ure is proportional to the serond Jerivalives of llar l()F function. surfare foren morleling rin l, wery m-nsitive Io small Hurtuations in $f$. possibly amplifying them

The ('SF formulation makr's use of the firct that unmerical mod.:Is of discontinuilies i! finte solume and linite differener schemes are really eomtinucols 1 ransitions withil, which the lluid propertios. vary smoothly from

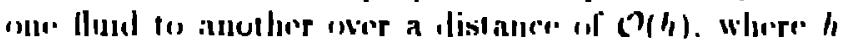
is a lergth romparable to the resolutioul alforded loy a compurational mesh with rpacing $\lambda_{x}$. It is mot appro. priate. a pressure jump iuluced by surface lansiou al a free

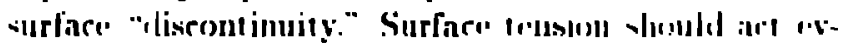
"rywhere wuthin the Iransition reguen. Hamely thromph Ihe wolume forer $\mathbf{F}_{4}$.

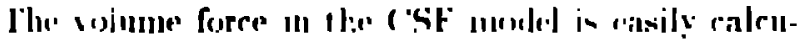

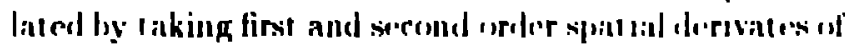

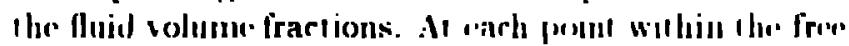

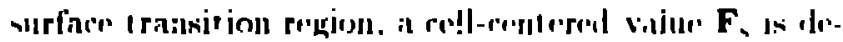

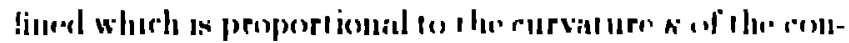

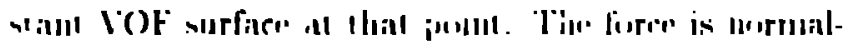

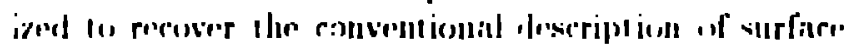
lension is the local product sh - 1). Its line intergral lirected normally through the free surfare Iransil ion region is approximately optuial lo the surface pressure in repuntion Wall adhesion is incorporalmd by enforeing a simplo loundary rondition.

Surfare imsion node 'od with the centinumm method eliminates the need for anterface reconst ruetion. so rest rictions on the number. complexity, or lỵnamic nvolution of interfaces lavi:ag surface tellsion are not iulposed. Direct comparisons berwern moteling surface lensiena with the ('St model and wilh a popular inlerfare reconst rurtion monlel sliow that the e SSF model Ilakkes more arcurate use of volumo fraction dat a. [2] The

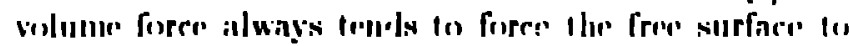
sork a minimum surface courgy conliguration. I?reon-

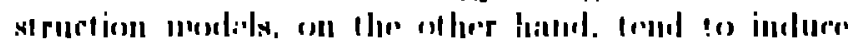
mumerioal noiso from romputed grainimess in the sur-

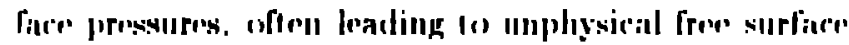
disruplions. In addition to providing a toore arrurales

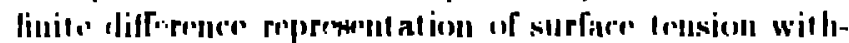

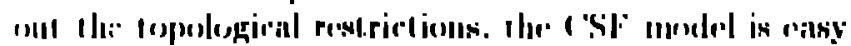

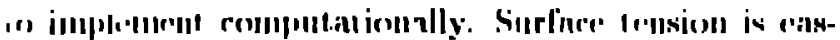

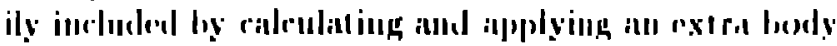

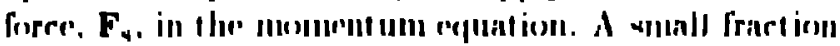

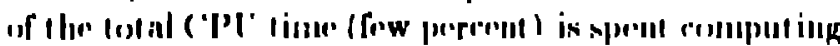

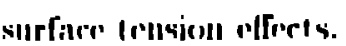

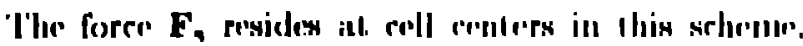

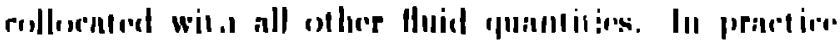

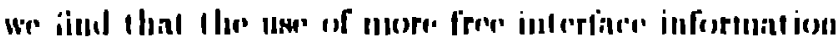

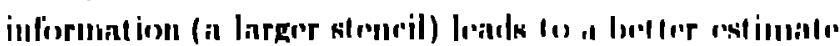

ul curvature. This apperars lo be the case for $F_{y}$ at

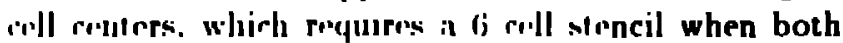
'ompunents of inferfare lumrmal $\vec{n}$ are collocated at faces. A rell-enlererl force is then ohtomed by summing over rell fares. Which hrongs the etfertive stencil to 9 cells.

The "optimal" liserete appeximation of $F_{B}$ in the ( 'SF molol is likely in he alle that properly accounts for the dualaty of Ireveling at litge slencil for accurate curuture citimates ind at compacl strencil for maintaining the locality uf volume force. ()ur current operators for F, are foumd in give the god results in practice. They ire mu necressirily oprimal. and rertainly hy no means

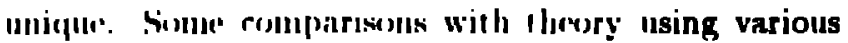
lifferenre axprossions for $F_{h}$ rin be found olsewhere.[2]

$A$ smocothed salue of the curvature $\alpha$ can be computed frim mpuation ?" ly using a simonthed lOF function

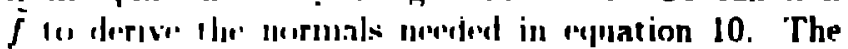

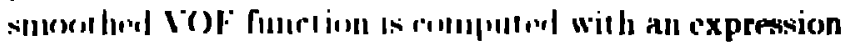
of the li,rm!

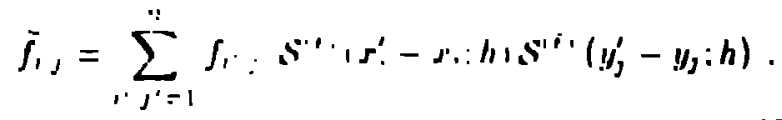

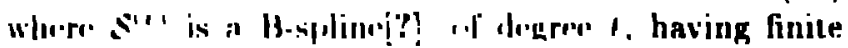
silpport. $5^{\prime \prime}\left(\mu^{\prime}-s: h\right) \neq \|$ inly lior $r^{\prime} \cdot s<(\ell+1) h / 2$. This smoos hing lends la mitughlo l he high wavenumber ront ributions in a. Which may ur may not be a regult of

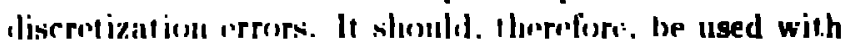
raution loreause the real frer surface gerometry might he unphysirally mollilied. Fixampless of the smoothing

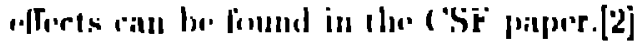

Ther repressentalion of surfare lension in the (SF moolel as a time /" lunly foren is linearly stable only for timr steps smaller than il certain maximum allow: ahle value $\lambda_{i}$, eeressary in rewolve the propagation of rnpillary waves.[2] evnluaterl is

$$
\lambda_{1}<M_{4}=\left[\frac{1 . J_{\operatorname{lnmin}}^{; 3 /:}}{1 \pi \sigma}\right]^{1 / 2} \text {. }
$$

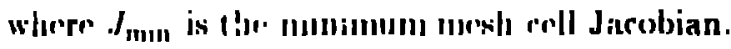

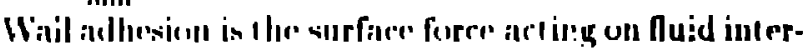
fares at proills of rentarl wilh "whlls." which are gtatic, rigicl houn:laries. Wall alhesion force's are calculated in

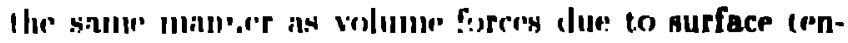
sion are raleulaled. excrept llat a lumulary rondition is ipplied lo the free surfare unit normal n prior to evalmaling enuntion III. The comelition is applien only fo

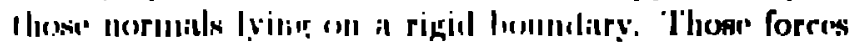
F, altribuled lo wall alleesion are l leerefore conly in cells aloug a bouludiary.

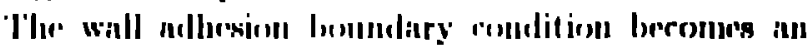

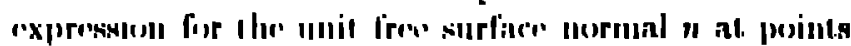

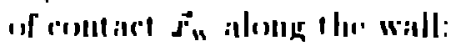

$$
\|=\|_{w} \cos \left(\theta_{b \cdot 1}+t_{w} \sin \theta_{n \cdot 1,}\right. \text {. }
$$




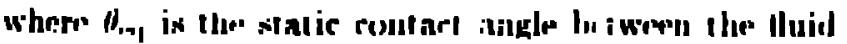

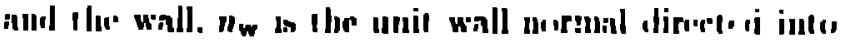

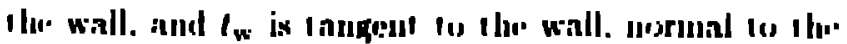
$\therefore$.

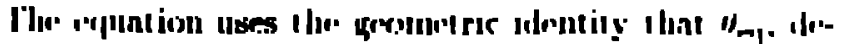

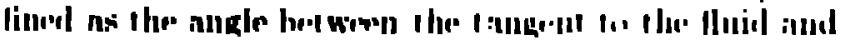

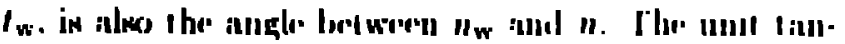

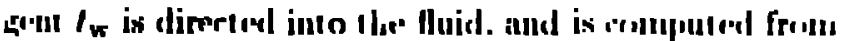

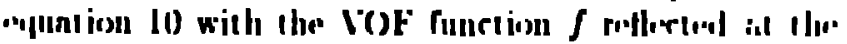
wall. Ther anglo $\|_{-1}$ is s:ot a flucl material proporty. hut

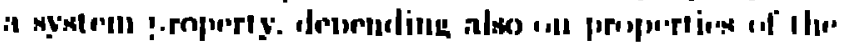

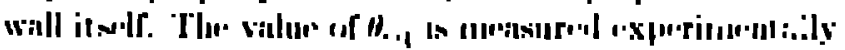
whell the lluid is al rest. Wie ampliamize thal the wail

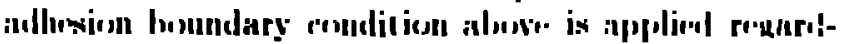

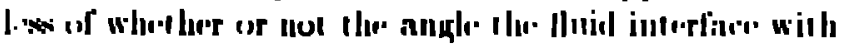
I hic wall is artually e.pual in $\|_{\text {m. }}$.

\section{Algorithm Summai:}

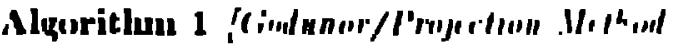

1. Silarl wilh dala $u^{\prime \prime} . f^{n} .0^{n+!}$

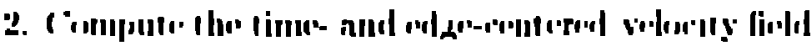

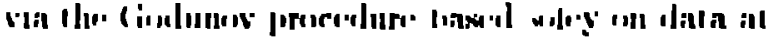
limir $n$.

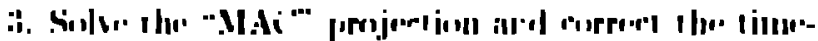

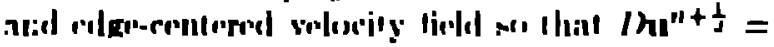
II.

I I sing "1"+⿱亠䒑 " II) " + I.

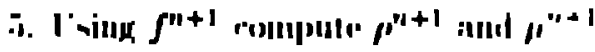

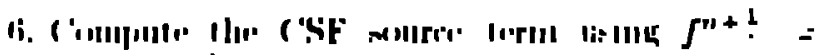
$\left(\rho^{\prime \prime}+\rho^{n+1}\right) / 2$.

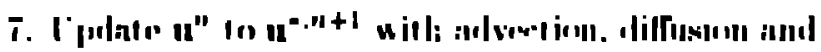
('SF mollrriw.

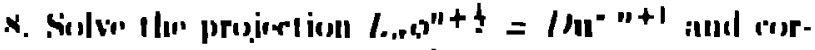
rurl th.' vilorition ln unt

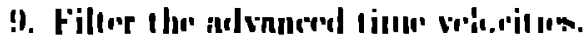

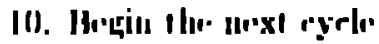

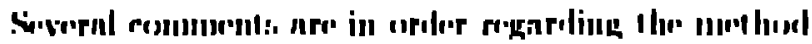

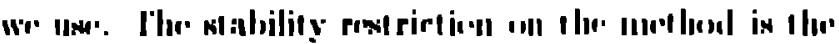

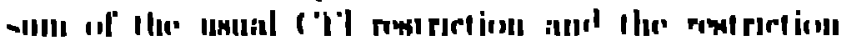

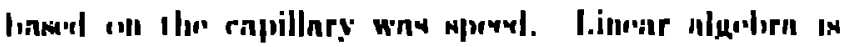

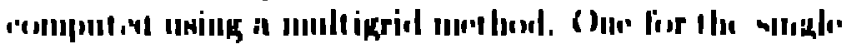

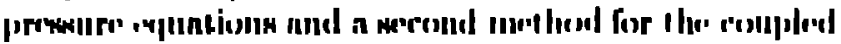

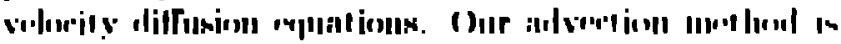

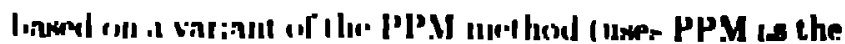

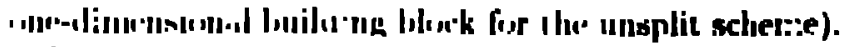
Vilunu tracking in 'ollupute-1 using nn unsplit methody

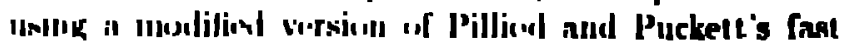
lonet seluares nleurithlu.

\section{Nimurical Examples}

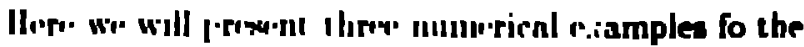
morthuds wo heve ulesirtiluel. The lirst exnmple is a drop

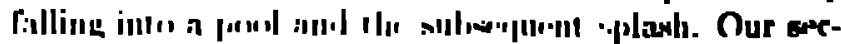

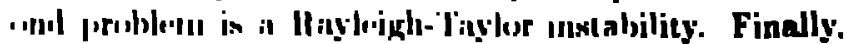

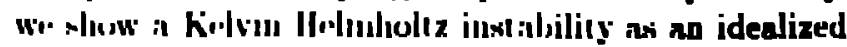
llow , al wiml were water.

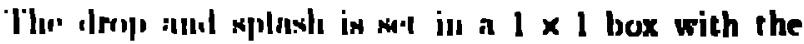

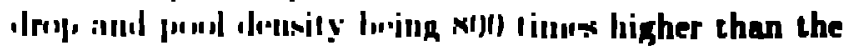

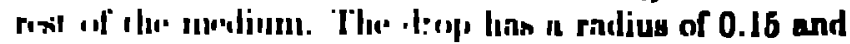
is '

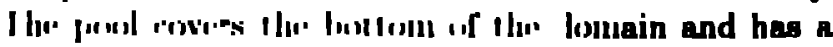

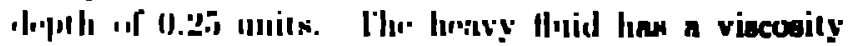

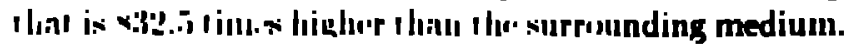

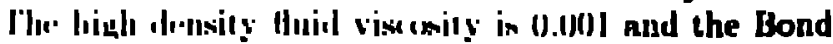

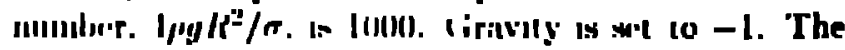

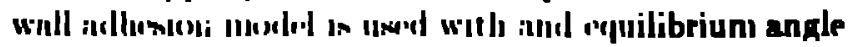
if lis degreys.

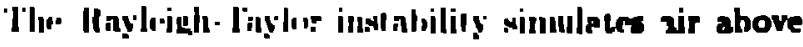

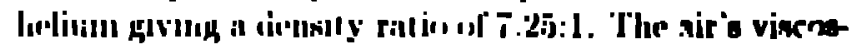
ty is 1. uti tiuns larger ihan thr hrliun. The compure-

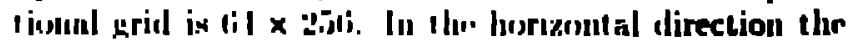
loman is poriodia. limvily is : I I - I A perturbation is ippliond to the vertirial verlority of

$$
r=11.01) 5[\operatorname{row}(2 \pi r)+1] \text {. }
$$

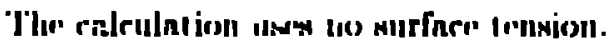

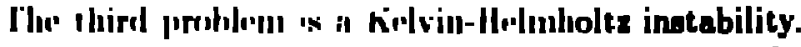

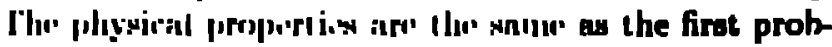

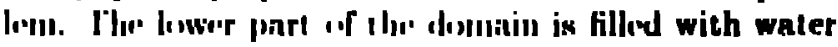

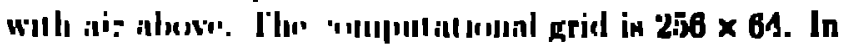

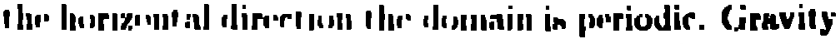

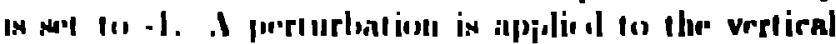
vilorily if

$$
r=11.100 i)[\operatorname{row}[2 \pi \Omega I+1] \text {. }
$$

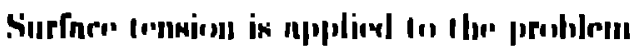

\section{Future Dirrotions}

\section{Rofierencess}

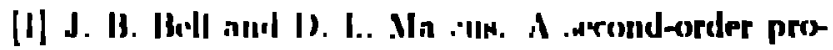

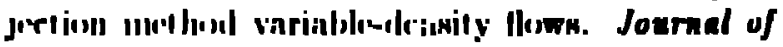

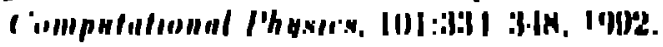

[2] J. I'. Mrarkhill. I). It. Kuslır, anll ('. Zemach. A

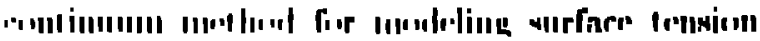




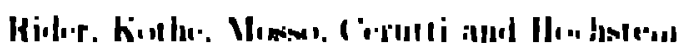

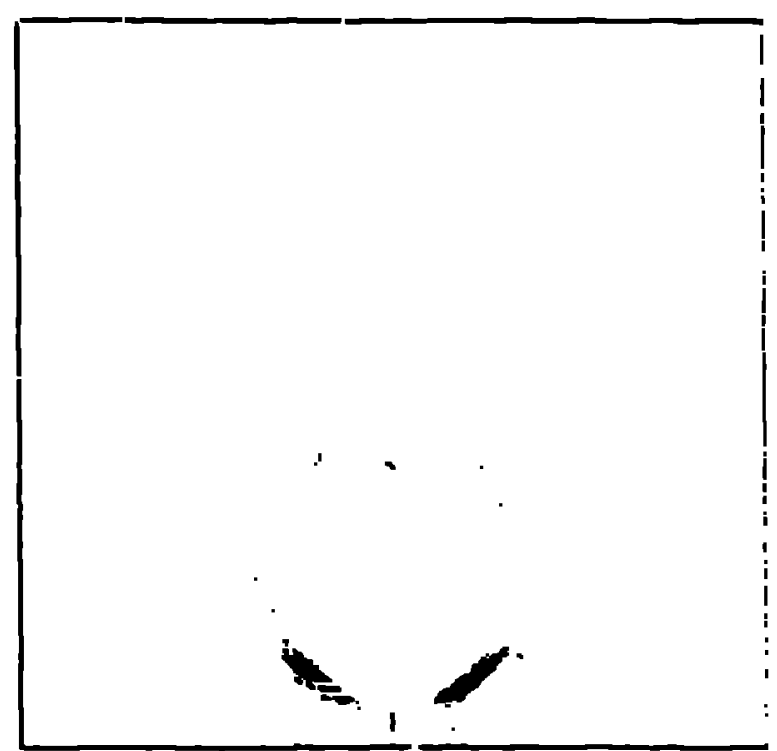

In) r-solou'it y

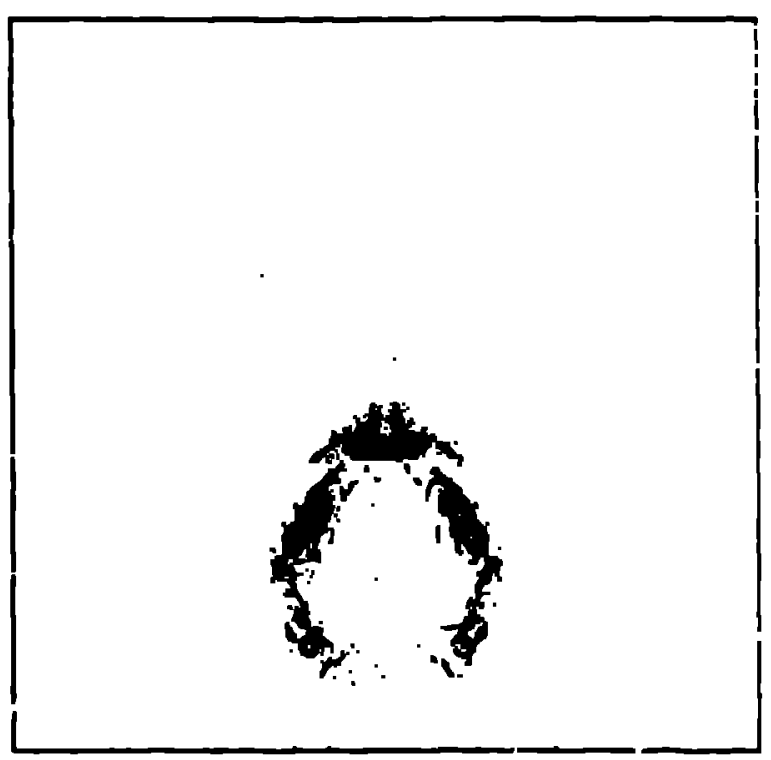

(a) promall p

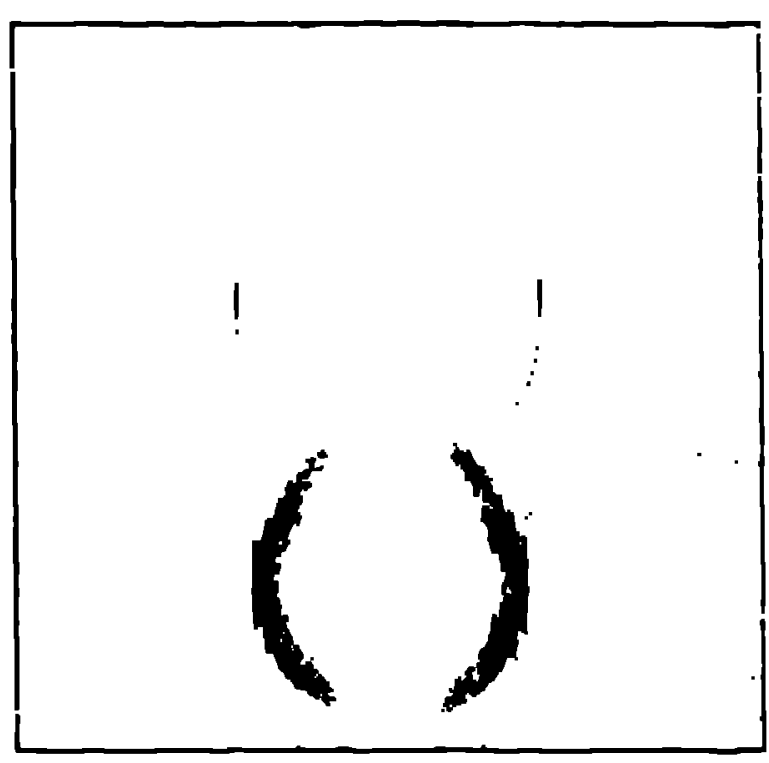

(l,) 4-volan-it v

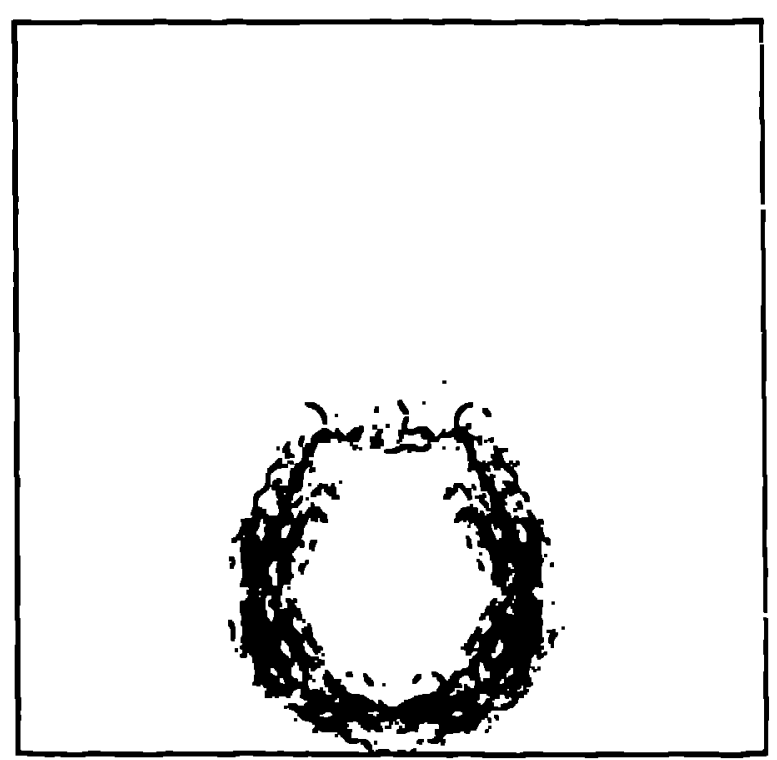

(d) $m a^{n+1}$

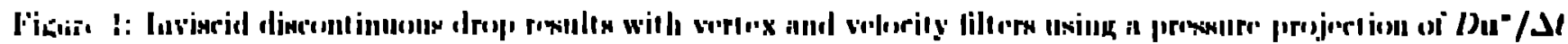
nutcl the nimp-proint formulation. 


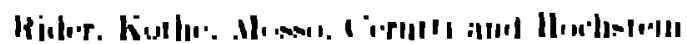

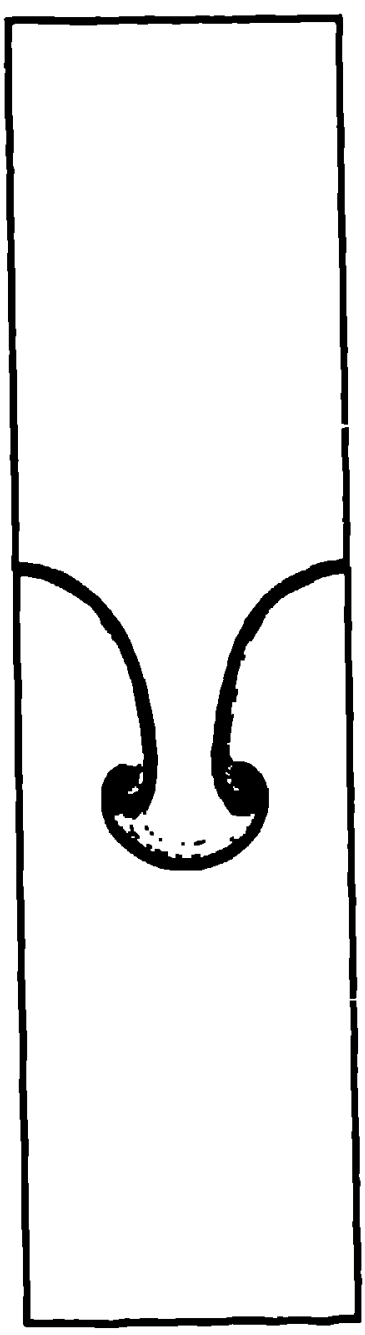

(i) $1=3.50$

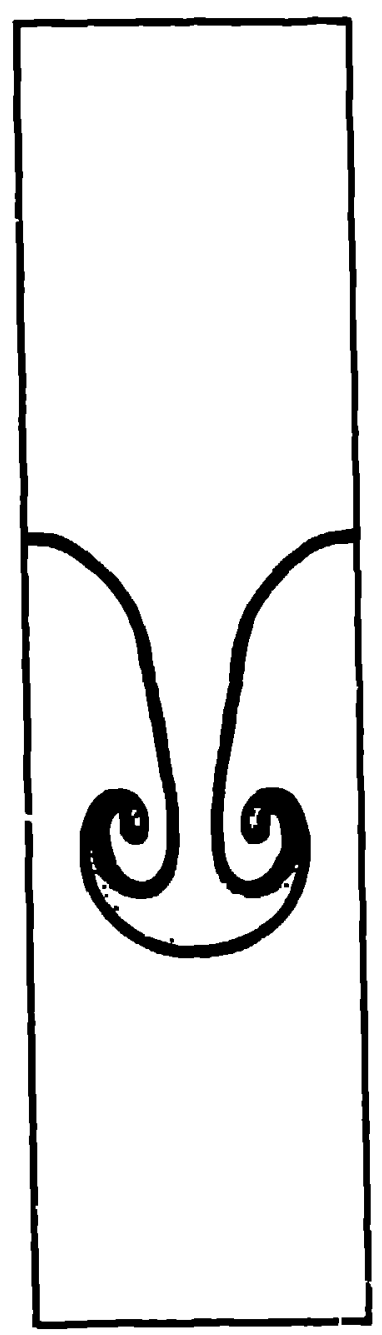

(b) $1=1 .(0)$

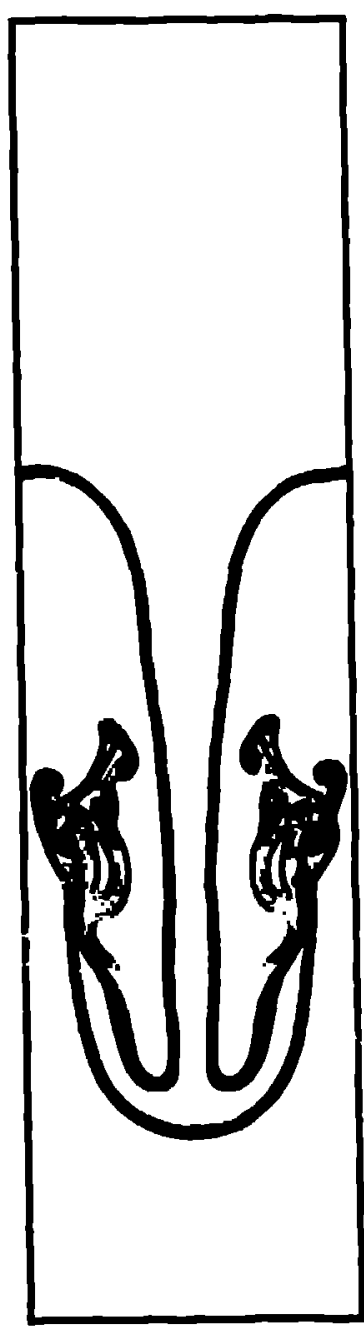

$(1 \cdot) 1=.1101$

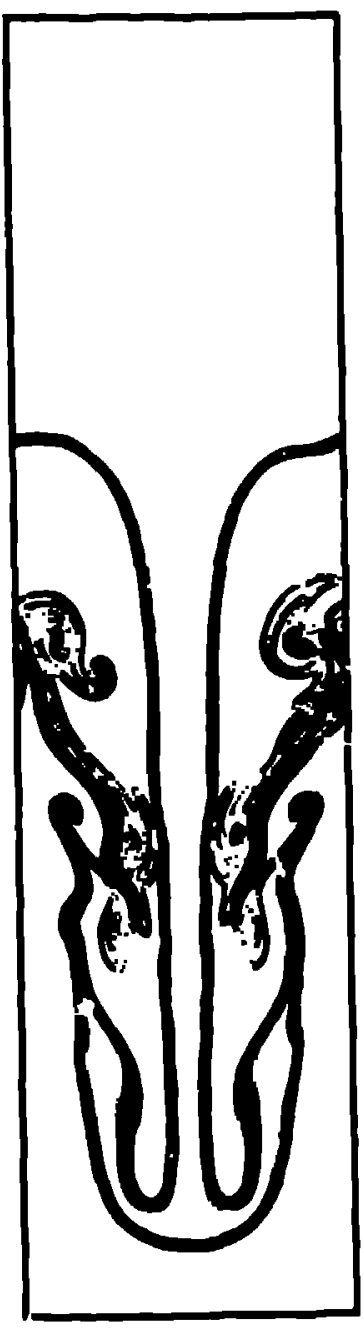

(d) $t=\pi$, int

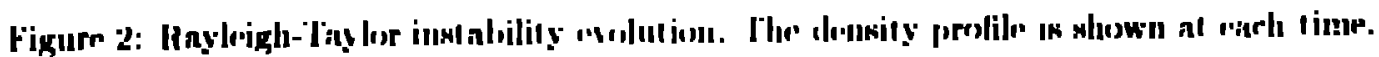




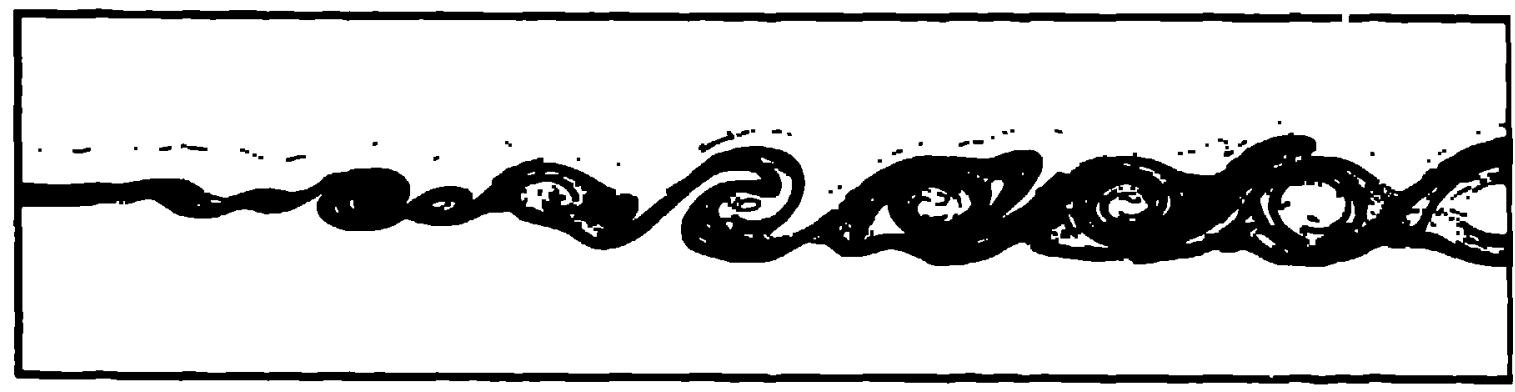

$\{+1=7.11$

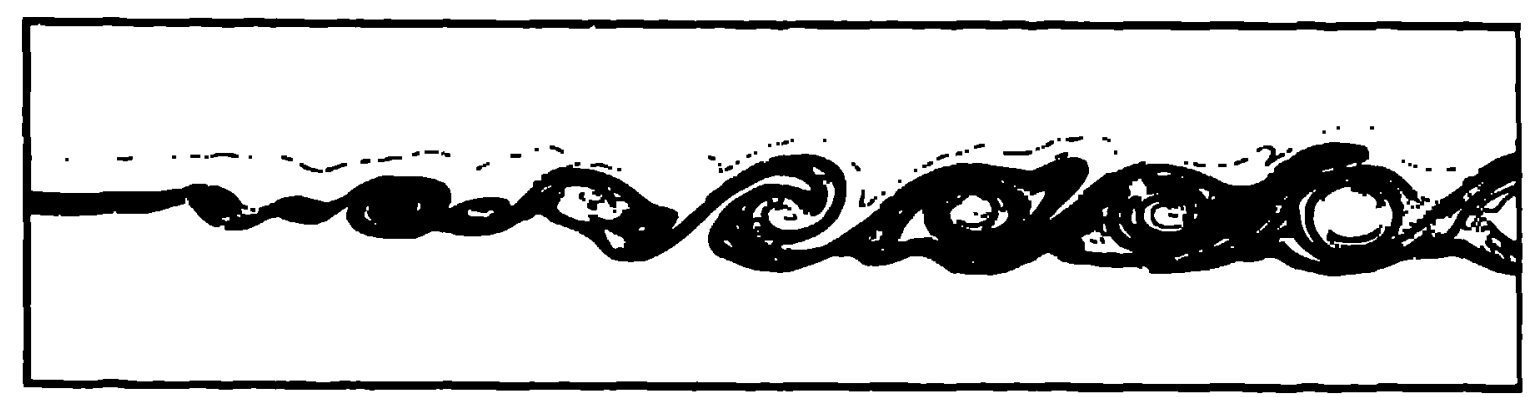

$\mid($ b) $1=-. . \mathrm{Hi}$

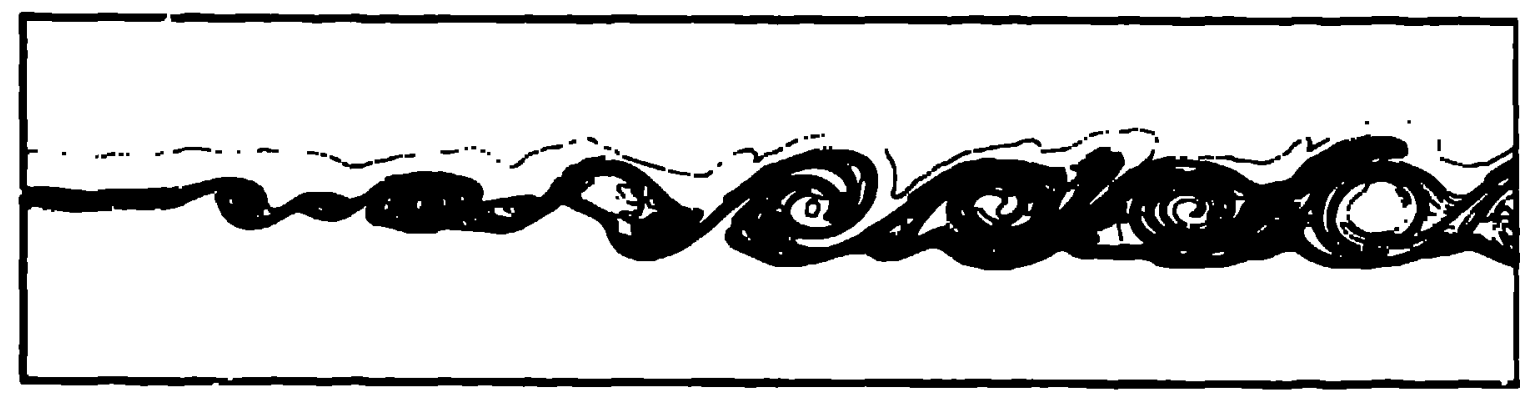

(1.) $\ell=\mathbf{T} .1 .5$

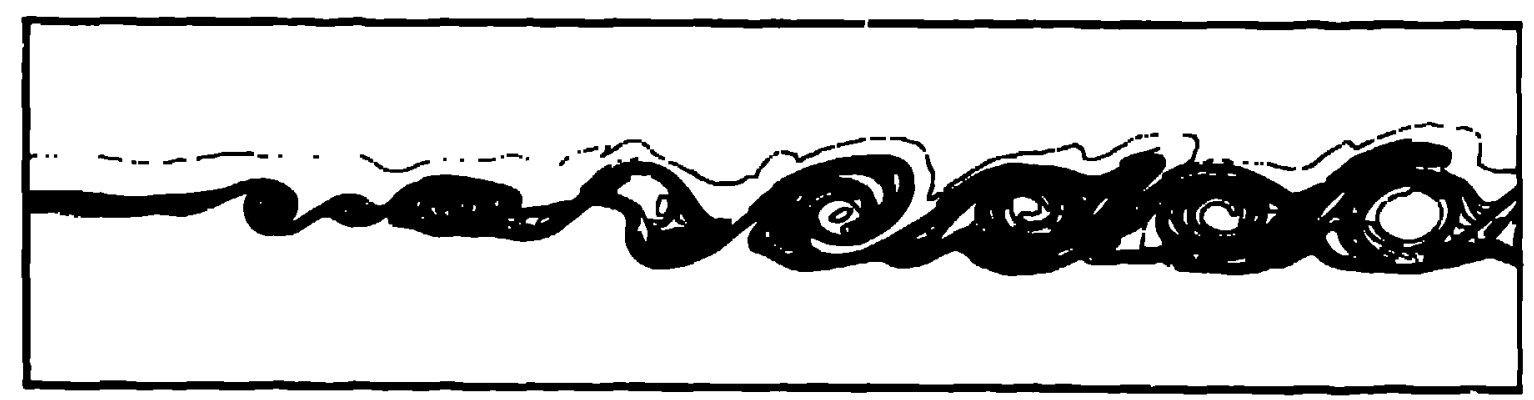

(d) $t=T . .6 i$

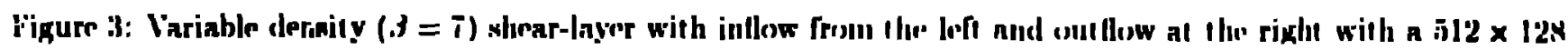
gricl. The cheneity prolile in show'n. 


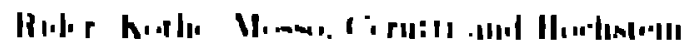

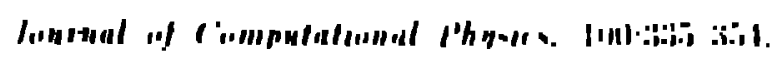
I!!!!2

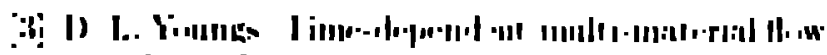

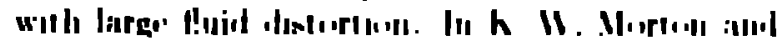

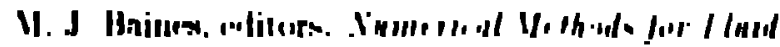

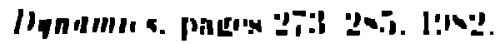

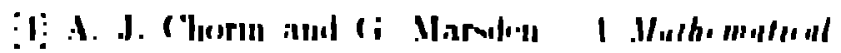

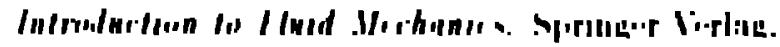
$1 ! 13$

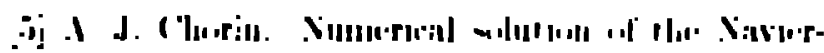

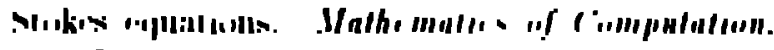

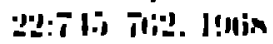

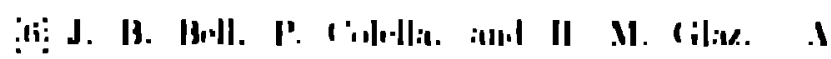

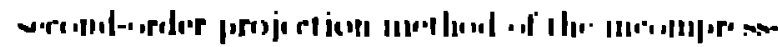

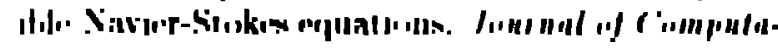

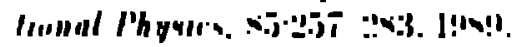

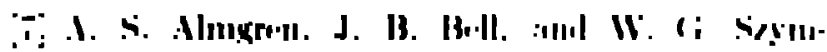

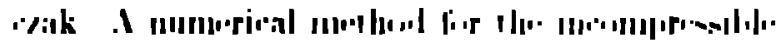

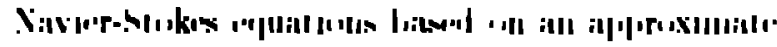

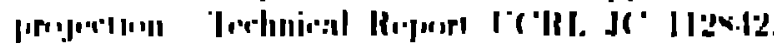

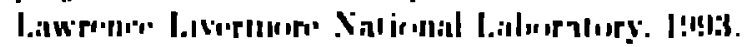

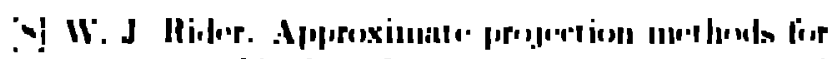

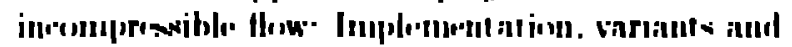

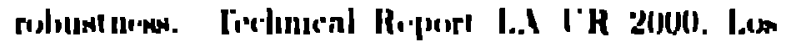

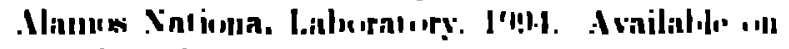

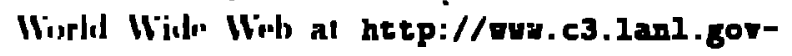
/c1c3/publications/aain. shtal.

[!)] II. J. Hider. The rohust formulation "I il]-

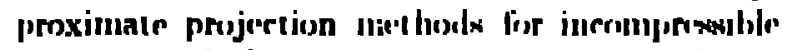

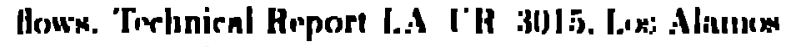

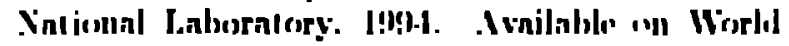
Wiile lliph il http://uvg.c3.1anl-gov/cic3/pablications/main.shtml.

[III] IV. J. Kieler. Filtering IImenleneselal mosles

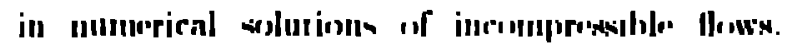

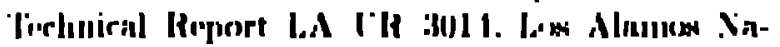
lienal Laboratory. I!II!.1. Ivailnble onl Wirlul Widv liph ht http://ru.c3.1anl.gov/cie3/publications/anin. ehtrin.

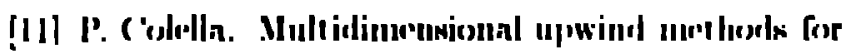

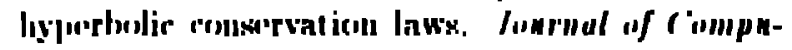
Intional Phymes. Ni:17 I 2(K), I!I!).

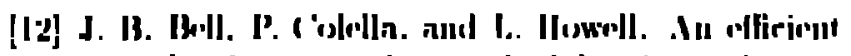
swrond-order projertion unethod for viscoun inconiprowsiblo flow. In I). Kuak. evlilor. Irocerdengs of the ildid Thath ('ompuluhonal H'lud Dynam-

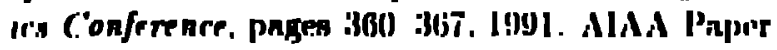
(1) 1inisil.

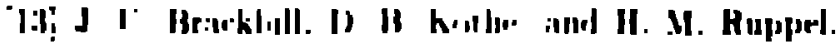

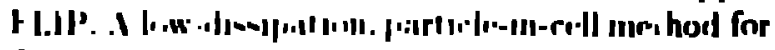

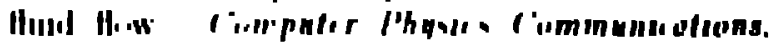
10.2:i is. I:104

11! (1) I lisereli illel (; Irvegvasem. A front-

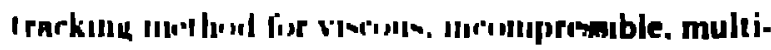

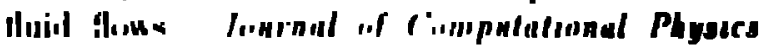

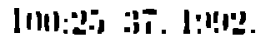

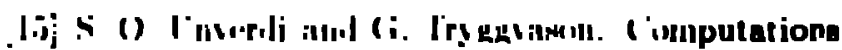

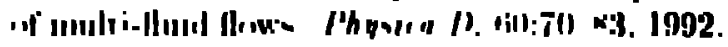

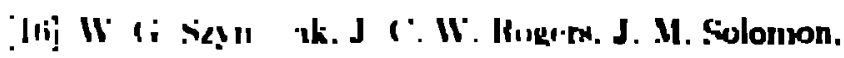

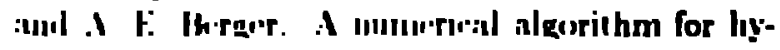

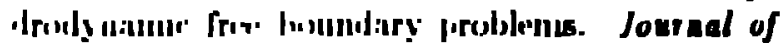

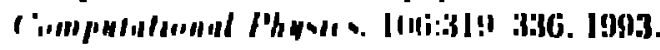

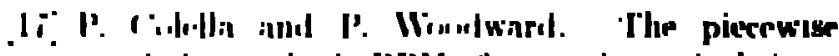

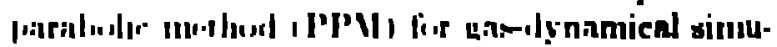

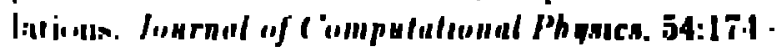
:I,I. I!!a)

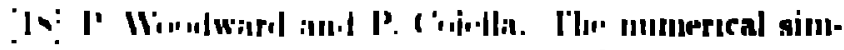

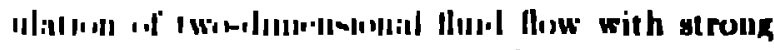

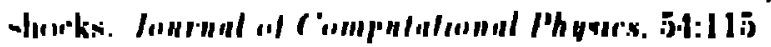
I7.3. I!IN.I.

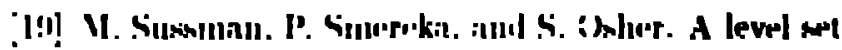
ilpprosirh fior icompul ung wilutusus lo incomprecoible Iwo-phase. llow. Jonrnal ij ('impufalınad Physucs. II.1:1.11; 1.j.). I!1!1.1.

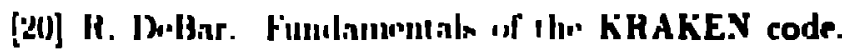

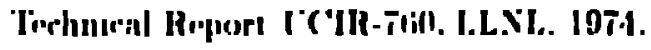

:2I] K. S. Ilolian. S. J. M(mw). I) A. Mandell. and H. II-nninger. MFSA: A :-D romputer code for armor/anti-armur applicatiuns. 'Turhnical Report

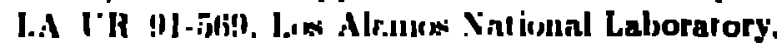
II)MI.

[22] J. S. Iיorry. K. I; Budge. M. h. W. Wong, and I. (i. Trumno. Hhale: A :-IJ MIMALE code for uns ruriurenl urids. In . ISIIl:. e.litur. .Idranerd romputafiomul IIfthods for Malirial .Modeling. A.WD.

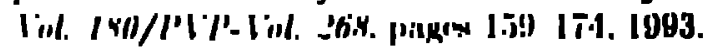

[2:3] W. F. Woh and I'. IR. Wiod/wnrel. SI.IC' Inimple line interfare merlhol). In A. I. van de Viuoren and P. J. Znurlbergen. exlitors. Leclure Jioles in Phyours 59. pangess :3330 :310. I!17(i).

[2-1] ('. IV. Ilirt and H. D. Nirlugls. Volune of fluid

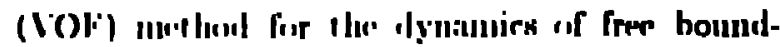

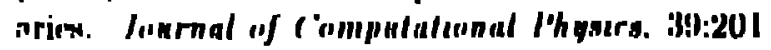
225. III)

[2ij] D. I. lisungs. An interfare trarking nethod for a 3I) Eulurinu hyllodynamure ander. 'Terhnienl the-

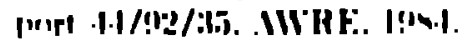




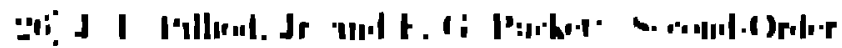

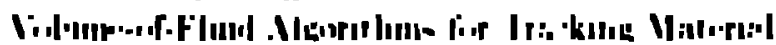

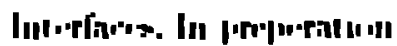

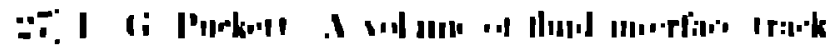

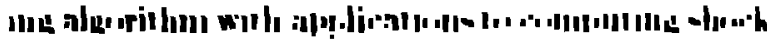

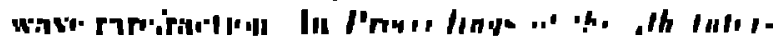

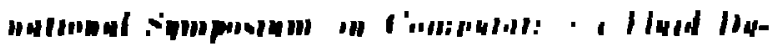

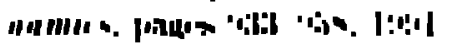

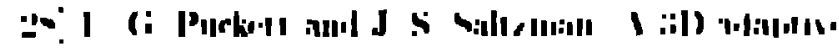
Imo m re fill lue-lit :

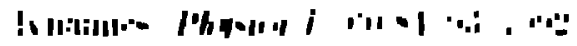

